\title{
THE IMPACT OF ORGANIZATIONAL CULTURE, ORGANIZATIONAL STRUCTURE, AND JOB-SATISFACTION ON HIGH SCHOOL TEACHERS' JOB-PERFORMANCE
}

\author{
Wesly Hutabarat \\ Faculty of Mathematics and Basic Science The State University of Medan \\ email:barathuta@gmail.com
}

\begin{abstract}
This study was a causal espouse fact study intended to find out and uncover direct and indirect effects of organizational culture, organizational structure, and job-satisfaction on teachers' jobperformance. The sample consisting of 143 out of 645 public high school teachers were selected from 10 senior high schools by using the stratified random sampling technique. The teachers were those having teaching experience of at least 10 years and they had been certified as professional teachers and received certification fees continuously, except for guidance and counseling teachers. The findings showed that organizational culture, organizational structure and job-satisfaction had a positive impact on teachers' job-performance. The direct and indirect effects of organizational culture on job-satisfaction were $21.20 \%$, and $10.00 \%$ respectively. The direct and indirect effects of organizational culture on job-performance were $23.20 \%$ and $22.80 \%$ respectively. The direct effect of organizational structure on job-performance was $29.50 \%$. Meanwhile, the indirect effect of organizational structure on job-performance was not significant. Finally, the direct effect of job-satisfaction on job-performance was $18.60 \%$.
\end{abstract}

Keywords: organizationa culture, organizational structure, job-performance, job-satisfaction

\section{DAMPAK BUDAYA ORGANISASI, STRUKTUR ORGANISASI DAN KEPUASAN KERJA TERHADAP KINERJA GURU SMA}

\begin{abstract}
Abstrak: Penelitian ini merupakan penelitian kausal espouse facts yang dimaksudkan untuk mengungkap efek langsung dan tidak langsung budaya organisasi, struktur organisasi, dan kepuasan kerja terhadap kinerja. Sampel terdiri atas 143 dari 645 guru SMA yang diambil dari 10 SMA di Medan yang diambil dengan teknik stratified random sampling techmiques. Sampel guru paling tidak memiliki pengalaman mengajar 10 tahun dan telah disertifikasi sebagai guru profesional. Data dianalisis dengan teknik regresi dan sebelumnya telah diuji normalitas dan linearitas sebarannya. Temuan penelitian menunjukkan bahwa budaya organisasi, struktur organisasi dan kepuasan kerja memberi dampak positif terhadap kinerja guru SMA Kota Medan. Pengaruh langsung dan pengaruh tidak langsung budaya organisasi terhadap kepuasan kerja masing-masing 21,20\%, dan 10,00\%. Efek langsung dan tidak langsung budaya organisasi terhadap kinerja masing-masing 23,20\% dan $22.80 \%$. Efek langsung dari struktur organisasi terhadap kinerja ada $29,50 \%$, sedangkan pengaruh tidak langsung dari struktur organisasi terhadap kinerja tidak fignificant. Akhirnya, efek langsung dari kepuasan kerja terhadap kinerja ada $18,60 \%$.
\end{abstract}

Kata Kunci: budaya organisasi, struktur organisasi, kepuasan kerja, kinerja

\section{INTRODUCTION}

Job-performance is defined as worker's outcomes in achieving organizational objectives in which he/she works.Teachers' job-performance determines their job-performance quali- ties in enhancing and developing National Education growth.Job-performance of public high school teachers could be identified based onthe achievement of teaching objectives. 
Research findings showed that job-performance of high school teachers in Medan is low. Based on the ranks of International Achievement Test Performance, Indonesia ranked $50^{\text {th }}$ of 87 countries involved in the test (Tienken, 2008:8). In addition, the Program for International Student Assessment (Pisa, 2012:16) results showed Indonesiaranked $64^{\text {th }}$ of 65 countries. This may be caused by the fact that $63 \%$ of the public high school teachers are not certified on their expertise, and $14 \%$ of them teach subjects which are not their expertise (Jalal, 2005:9; Upu, 2014:33; Suryadharma, 2011:15; Sanaky, 2011:3).

Indonesian governments have tried to improveteacher job-performance thorugh administrative and teachnical changes. Administrative changes concern the organizational structure changes, such as the use of the school-based management (SBM) instead of the Weber/bureucratic system. Meanwhile, technical changes involve service, products, and technological development, training, profesional develompment, computer facility procurement, and teacher competency assessment (The World Bank, 2007:15; Syamsudin, 2012:2; Colquitt, at al, 2009:452).

The teacher certification program resulted in increasing teacher work motivation which can be seen from their interest in pursuing higher degree of education (bachelor and masters degrees). It was also predicted that teachers are motivated to join scientific conferences in their own expertise in order to meet requirements for the certification program, and in truns it increases teachers' quality. Unfortunately, it was found that the teachers certification programhas noeffect on teachers' job-performance (Fahmi, et al, 2011:1)

Teachers who are certified would get additional montly payent called certification salary that would have a great impact on teachers' job-satisfaction, and it means that satisfied employees are productive employees (Thierry, 1998: 256). Therefore, job-satisfaction could be seen as aprecursor for job-performance (Miles and Sledge, 2006:2). Ehrenberg (2003:268) found that higher educated workers would have higher job-satisfaction compared with those with lower education. As a result, it is presumed that high school teachers' job-performance are moderately higher for high school teachers (Judge, et al., 2001:378). It is also known that organizational culture has an important role in increasing teachers' job-satisfaction (Sabri, et al., 2011: 121). Furthermore, it also found that organzational culture affected job-satisfaction and job-performance (Ambarita., 2010:195; and Siburian, 2012:1).

Job-performance is defined as employees' job-performance which meet the organizational objectives (Viswesvaranand Ones, 2000:216). Teachers' job-performance is usually affected by school facilities, classroom size, leadership style, motivational strategy and teacher morale (Adejumobi and Ojikutu, 2013:26). Generally, measurable behaviours are used as indicators of job-performance. It is usually carried out in order to (1) find out credible, relevant, and useful information, so it can be used in the decision making process on current and future organization performance; (2) identify organizational peformance and growth; (3) plan and carry out training and development; (4) carry out remuneration and rewards; and (5) design career development and successions (Chiepe, 2004:10).

An evaluation of teachers' performance could be carried out by considering the following rubric: (1) professional knowlwedges; (2) teaching plan; (3) teaching strategy; (4) individual teaching and remedial; (5) evaluation techniques; (6) feedback; (7) teaching-learning environment; (8) challenging academic environment; (9) professionalism; and (10) communication (Barge, 2012:4).

Organizational culture is defined as social relationships between organization members, considered as a way of life in an organization (Penilaian Kinerja Guru, 2008:22; Schein, 2004:17). In general, organizational culture is different from one organization to another, because it is usually developed in the organization for a long period of time. Organizational culture allows organizational members to coordinate activities comprehensively, comprehend and predict employees' behaviors, beliefs, and work motivation of the employees. 
Schein (2004:17) emphasized that organizational culture could be determined through (1) artefacts; (2) norms and values; (3) basic assumptions (Colquitt, et al., 2009:456). In general, there are five artefacts i.e symbols, physical structure, language, stories, ritual, and ceremony. Symbols concern the organizational logo, work environment, while physical structure concerns: organizational relationships to the public, manager relationships with other members of the organization, and employee democracy (Colquitt, et al., 2009:458). Language is a communication means inside organizations. Meanwhile, stories concern anecdots, legends, and myths which are taught from one generation to another in the organization. Ritualis are defined as daily or weekly activities in the organization. Espoused values concern the organizational norms and philosophy which are expressed explicitly. Espoused values are published documents such as vision and mission statements of the organization, including verbal statements of managers which are directed to employees. The basic underlying assumptions concern the organizational phylosophy and beliefs which are generally accepted without questions (Colquitt, et al., 2009:460). Therefore, organizational culture can be presumably determined through observable behavior, values and beliefs and basic assumptions.

Organizational structure is defined as a formal organizational structure in an organization, in whichthe organization allocate people and jobs so that their work can be performed tomeet the organizational objectives (Elsaid, et al., 2013:1; Robinand Coulter, 2007:298). The basic concepts of organizational structure describe the organizational framework of organizations (Lunenburg and Ornstein, 2000:27). In general, the traditional organizational structure is known as having a vertical structure which has a pyramid shape that is useful in stable circumstances, but not in a rapid environment change. In the vertical structure, managers and employees are not closely related, so it creates a gapamong departments. As a result, it prevents coordination and quick responses between top and lower managers. Currently, most organizations have tried to change from the vertical structure into the horizontal structure based on the working process instead of departmental functions because in the vertical sturcture, activities are classified into the same functions from lower to top managers. Therefore, a vertical organizational structure is known as a rigid organization based on Weber's organizational system (Daft, 2005:602).

In order to change the organizational structure, the organization basic charactersneed to be changed to meet organizational objectives (Lunenburg and Ornstein, 2000:30). One of the organizational structures introduced to replace the vertical sturcture for the schooling system is the school-based management (SBM) which delegates the managerial decision making process from top managers to lower managers (Caldwell, 2003:2).

Job-satisfaction is defined as an employee's emotional state and statisfaction as a result of managers' evaluation on his/her job that meetsthe organizational objectives (Tella, et al., 2007:4). Therefore, the satisfied employees would have positive thinking at work (Colquitt, et al., 2009:548). Maslow described that there are a number of factors which could affect jobsatisfaction i.e. biological and physiological needs, safety needs, belongingness and love needs, esteem needs and self actualization needs. People would statisfy the lower needs first before satisfying the higher needs. (Colquitt, et al., 2009:549). Maslow model could be used in developing teachers' job-satisfactionby considering teachers' needs at work.

Furthermore, it is also known that job-satisfaction is affected by payment-satisfaction, promotion satisfaction, social satisfaction, supervision satisfaction, co-workers satisfaction, work satisfaction itself, status statisfaction and environmental satisfaction (Slocum and Hellriegel, 2009:355). Therefore, job-satisfaction could be seen as the main factor that affects job-performance that determines educational success and teacher job-performance (Ololube, 2009: 56). It is presumed that teacher job-satisfaction could be determined by payment-satisfaction, promotiona satisfaction, social satisfaction, 
supervision satisfaction, co-workers satisfaction, work satisfaction itself, status statisfaction and environmental satisfaction.

Another question is, why do we have a tendency to produce less qualified teachers from colleges? It is also due to the fact that students who enrolled into teacher colleges come from low grades and the best and brightest students do not choose teaching as their career option. Therefore, teacher colleges would only produce teachers with low quality (Ballou and Podgursky, 1998:20). This is one of the many factors suggesting that teacher quality is the most important factor in determining differences in students'achievement (Goldhaber, 2002: 3). Therefore, job-satisfaction could be seen as the main factor that affects job-performance that determines educational success and teacher job-performance (Ololube. 2009:56). It is presumed that teacher job-satisfaction could be determined by payment-satisfaction, promotional satisfaction, social satisfaction, supervision satisfaction, co-workers satisfaction, work satisfaction itself, status statisfaction and environmental satisfaction.

\section{METHOD}

This study is a causal research study which tries to discover causal relationships between the organizational culture, organizational structure, and job satisfaction toward job-performance of senior high schoolteachers, in Medan Indonesia.The research method used is a survey method based on explanatory and confirmatory approaches.

The population of this research is teachers of 10 senior high schools in Medan Indonesia. The sample was selected by using the stratified random sampling technique. The selected teachers must have teaching experience of at least 10 years, except for guidance and counseling teachers. They must have been certified and have received additional teacher certification payment regularly. The research instruments (organizaional culture, organizational structure, and job-satisfaction questionnaires) were tried out to 30 teachers not belonging to the sample in order to find out their validity and reliability. The validated organizational culture, organizational structure, and job-satisfaction questionnaires consist of 34,32 , and 34 items respectively after being tried out. Meanwhile, the teacher job-performance assessment instrument was tried out to 30 teachers in order to find out the teachers' perception homogeneity in using the instrument.

The questionnaires were then distributed to 150 classroom teachers. The teachers were told about the objective of the study and they were allowed to ask questions when the statements in the questionnaires were not clear. The questionnaires were distributed to the teachers in the morning before the class started and during the break. There were 143 out of 150 questionnaires collected met the requirement as data used in the research. Furthermore, the teacher job-performance assessment was administered during the teaching-learning process.

Based on the organizational behavior theory, a causal relationship between $\mathrm{X}_{1}, \mathrm{X}_{2}, \mathrm{X}_{3}$ and $\mathrm{X}_{4}$ variables can be drawnas shown in Figure 1 .

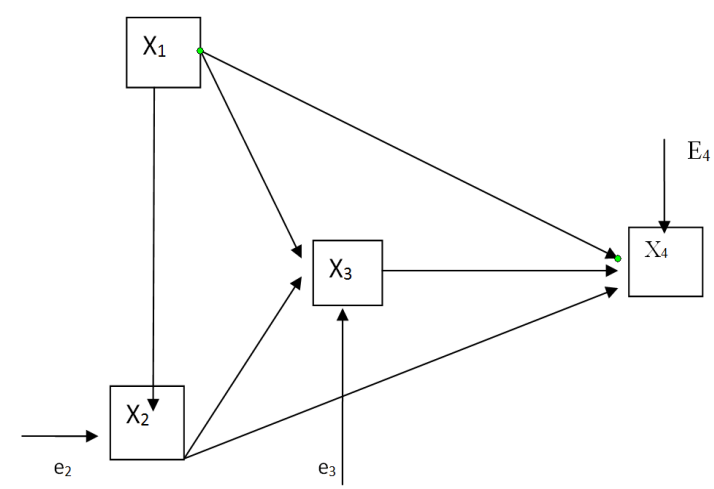

Figure 1. Causal relationship between $X_{1}, X_{2}$, $\mathbf{X}_{3}$, and $\mathbf{X}_{4}$ Variabels

The organizational culture, organizational structure, and job-satisfaction questionnaies, and job-performance data were collected and analized with SPSS for Windows Vers 21.

\section{RESULT AND DISCUSION}

\section{Normality and Linearity Test}

One-Sample Kolmogorov-Smirnov test was used to carry out normality test, and it was found that Asymp. Sig. (2-tailed) $0.170>0.05$, which means that data collected comes from a 
normal distributed population. Liniarity test was carried out by F-distribution test on the $X_{1}$. $\mathrm{X}_{2}, \mathrm{X}_{3}$, and $\mathrm{X}_{4}$ variables instruments and it was found that Deviation from linearity $>0,05$, therefore it can be concluded that the four variables are linear.

\section{Effect of Organizational Culture on Organizational Structure}

Before path analysis was carried out, it needs to find out correlation coefficients of $X_{1}$, $\mathrm{X}_{2}, \mathrm{X}_{3}$, and $\mathrm{X}_{4}$ using SPSS for Windows vers 21 . Then, path analysis was carried out in order to find out path coefficients of the variables investigated. Results showed that path coefficient of organizational culture to organizational structure is 0.399 at a significant level of $<0.05$ and $\mathrm{F}=26.714$, where $\mathrm{F}_{\text {calc. }}>\mathrm{F}_{\text {table }}=3.908$, at a significant level of $<0.05$ which means that $\mathrm{H}_{\mathrm{o} 1}$ is rejected, therefore it can be concluded that there is a direct effect of organizational culture on organizational structure of public high school teachers, in Medan. Meanwhile, determination coefficient $R_{\text {squared }}$ value found is 0.159 , so that $\mathrm{e}_{2}=\sqrt{1-R^{2}}=\sqrt{1-0.399^{2}}=0.917$.

\section{Effect of Organizational Culture and Orga- nizational Structure on Job-Satisfaction}

Based on ANOVA analysis, it was found that path coefficient of organizatioal culture to job-satisfaction is 0.212 , meanwhile path coe- fficient of organizational structure to job-satisfaction is 0.251 , and $F_{\text {calc. }}=12.404>F_{2 / 140 \text { table }}=$ 3.061 , at a significant level of $<0.05$, which means that $\mathrm{H}_{02}$ and $\mathrm{H}_{04}$ are rejected, therefore, it is concluded that organizational culture and organizational structure directly effect job-satisfaction. Meanhile, determination coefficient $\mathrm{R}$. squared value is 0.151 , so that $e_{3}=\sqrt{1-R^{2}}=$ $\sqrt{1-0.388^{2}}=0.921$.

Fisrtly, causal relationships between organizational culture and job-satisfaction can be written in the following equation:

$$
r_{13}=\rho_{31}(\mathrm{DE})+\rho_{32} r_{12}(\mathrm{IE})
$$

From equation 1) it can be determined that direct effect of organizational culture on job-satisfaction is $21.20 \%$ and indirect effect of organizational culture on job-satisfaction thorugh organizational structure is $10.00 \%$, so that $\mathrm{H}_{07}$ is rejected, which means that there is indirect effect of organizational culture on job-satisfaction through organizational structure.

Secondly, causal relationships between organizational structure and job-satisfacion can be written in the following equation:

$$
\left.r_{23}=\rho_{32}(\mathrm{DE})+\rho_{31} \mathbf{r}_{12}(\mathrm{~S}) \ldots \ldots \ldots . .2\right)
$$

From equation 2) it can be determined that direct effect of organizational structure on job-satisfaction is 0.251 , and spurious correlation is 0.084 .

\begin{tabular}{|c|c|c|c|c|c|c|}
\hline \multirow[b]{2}{*}{ Model } & & \multicolumn{2}{|c|}{$\begin{array}{l}\text { Unstandardized } \\
\text { Coefficients }\end{array}$} & \multirow{2}{*}{$\begin{array}{c}\begin{array}{c}\text { Standardized } \\
\text { Coefficients }\end{array} \\
\text { Beta }\end{array}$} & \multirow[b]{2}{*}{$\mathrm{t}$} & \multirow[b]{2}{*}{ Sig. } \\
\hline & & B & Std. Error & & & \\
\hline 1 & (Constant) & 71.426 & 7.247 & & 9.856 & .000 \\
\hline & bUORG & .359 & .069 & .399 & 5.169 & .000 \\
\hline
\end{tabular}

Table 1. Path Coefficients

a. Dependent Variable: $\mathrm{X}_{2}$

\begin{tabular}{|c|c|c|c|c|c|c|}
\hline \multirow[b]{2}{*}{ Model } & & \multicolumn{2}{|c|}{$\begin{array}{c}\text { Unstandardized } \\
\text { Coefficients }\end{array}$} & $\begin{array}{l}\text { Standardized } \\
\text { Coefficients }\end{array}$ & \multirow[b]{2}{*}{$\mathrm{t}$} & \multirow[b]{2}{*}{ Sig. } \\
\hline & & B & Std. Error & Beta & & \\
\hline 1 & (Constant) & 47.941 & 12.452 & & 3.850 & .000 \\
\hline & $\mathrm{X}_{1}$ & .250 & .100 & .212 & 2.494 & .014 \\
\hline & $\mathrm{X}_{2}$ & .329 & .111 & .251 & 2.958 & .004 \\
\hline
\end{tabular}

Table 2. Path Coefficients $X_{1}$, and $X_{2}$

a. Dependent Variable: $\mathrm{X}_{3}$ 
Table 3. Ptah Coefficioents of X1, X2, and X3

\begin{tabular}{llrrrrrr}
\hline & & \multicolumn{2}{c}{$\begin{array}{c}\text { Unstandardized } \\
\text { Coefficients }\end{array}$} & \multicolumn{2}{c}{$\begin{array}{c}\text { Standardized } \\
\text { Coefficients }\end{array}$} & & \\
\cline { 3 - 5 } Model & & \multicolumn{1}{c}{ B } & \multicolumn{1}{c}{ Std. Error } & Beta & & \multicolumn{1}{c}{ Sig. } \\
\hline 1 & (Constant) & 39.072 & 10.101 & & & 3.868 & .000 \\
& $\mathrm{X}_{1}$ & .231 & .079 & .232 & 2.926 & .004 \\
& $\mathrm{X}_{2}$ & .326 & .089 & .295 & 3.679 & .000 \\
& $\mathrm{X}_{3}$ & .157 & .065 & & .186 & 2.403 & .018 \\
\hline
\end{tabular}

a. Dependen Variable: $\mathrm{X}_{4}$,

Effect of Organizational Culture, Organizational Structure, and Job-Satisfaction on Job-Performance

Based on Anova analysis of $\mathrm{X}_{1}, \mathrm{X}_{2}$, and $\mathrm{X}_{3}$ on $\mathrm{X}_{4}$, it was found that effect of organizational culture, organizational structure, and job-satisfaction on job-peformance respectively are $0,232,(\mathrm{t}=2.926 ; \alpha=0,04) ; 0.295(\mathrm{t}$ $=3,679, \alpha=0,000$; and 0,186 $(\mathrm{t}=2,409, \alpha=$ 0,018 ), and $F_{\text {calc. }}=18,283>F_{3 / 139 \text { table }}=2,670$, at a significant lvel of $<0.05$, so that it is cancluded $\mathrm{Ho}_{3}, \mathrm{H}_{05}$ and $\mathrm{H}_{06}$ are rejected. It means that there is a direct effect of organizational culture, organizational structure, and job-satisfaction on job-performance It is found that determination coefficient $\mathrm{R}_{\text {rquare }} \mathrm{d}$ value is 0.294, so that, $\mathrm{e}_{4}=\sqrt{1-R^{2}}=\sqrt{1-0.542^{2}}=$ 0,840

Thirdly, causal relationships betwen organizational culture and job-performance is written in the following equation:

$$
\begin{aligned}
& r_{14}=\rho_{41}+\rho_{42} r_{12}+\rho_{43} r_{14}=\rho_{41}(D E)_{+}\left(\rho_{42} \rho_{21}+\right. \\
& \left.\left.\rho_{43} \rho_{31}+\rho_{32} \rho_{21} \rho_{43}\right) \text { (IE) } \ldots .3\right)
\end{aligned}
$$

From equation 3) above, it can be determined effect of organizational culture on jobperformance is 0.232 . and indirect effect of organizational culture on job-performance through organizational structure is 0.118 , indirect effect of organizational culure on job-performance through job-satisfaction is 0.039 (not significant) and indirect effect of organizational culture on job-performance through organizational structure and job-satisfaction is 0.019 (not significant).

Fourthly, causal relationships between organizational structure and job-performance is written in the following equation:

$$
\begin{aligned}
& r_{24}=\rho_{42}+\rho_{41} r_{12}+\rho_{43} r_{23}=\rho_{42}(D E)+\rho_{43} \\
& \rho_{32}(\mathrm{IE})+\left(\rho_{43} \rho_{21}+\rho_{43} \rho_{31} \rho_{21}\right)(\mathrm{S}) \quad \ldots \quad
\end{aligned}
$$

From equation 4) above, it can be determined that direct effect of organizational structure on job-peformance is 0,295 , and indirect effect of organizational structure on job-performance through job-satisfaction is 0,047 (not significant) or $\mathrm{H}_{08}$ is rejected, and spurious correlations is 0,090 .

Finally, causal relationships betwen jobsatisfaction and job-performance is written in the following equation:

$$
\begin{array}{ccc}
r_{34}=\rho_{43}+\rho_{51} & r_{13}+\rho_{42} & r_{23} \\
\rho_{43}(D E)+\left(\rho_{41} \rho_{31}+\rho_{41} \rho_{21} \rho_{32}+\rho_{42}\right. & \left.\rho_{32}+\rho_{42} \rho_{21} \rho_{31}\right)(S)
\end{array}=
$$$$
\text { (....... 5) }
$$

From equation 5) above, it can be determined direct effect of job-satisfaction on jobpeformance is 0,186 , and spurious correlation is 0,171 .

Based on data analysis above, teacher job-performance model of public high schools in Medan can be illustrated in Figure 2 below:

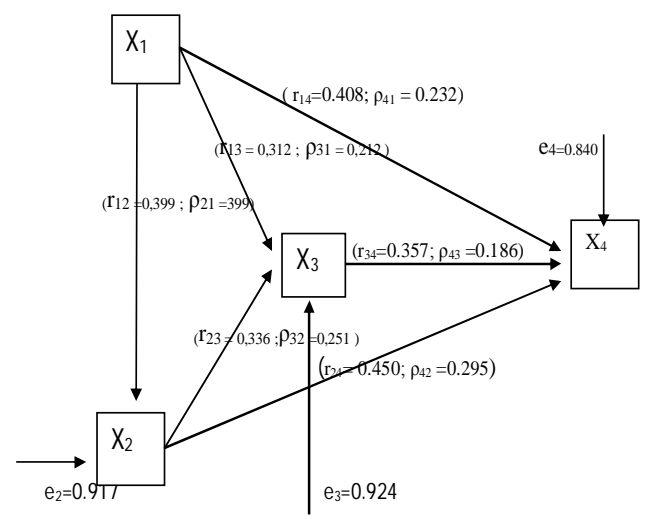

Figure -2. Teacher Job-Peformance Model of Public High School in Medan 


\section{Discussion}

Based on the results presented above, it is known that organizational culture, organizational structure, and job-satisfaction give a positip impact on job-performance of public high school teachers in Medan. It is proved that orgaizational structure changed from Weber's strutcture to school bansed management (SBM) gives a relatively high impact of $29.50 \%$ on job-performance, meanwhile indirect effect of organizational structur on job-performance through jobsatisfaction is not significant.

Effect of organizational culture onjob-performance and job-satisfaction respectively are $23,20 \%$ and $18,60 \%$. At the same time, indirect effect of organizational culture on job-performance is $11.80 \%$. Therefore, total effect organizational culture, organizational structure and job-satisfaction on job-performance is $83.10 \%$, Similarly, Suriansyah $(2014 ; 363)$ reported that organizational culture directly and indirectly affect teacher job-performance through teacher commitments of $10.10 \%$, and $16.90 \%$ respectively. It was also found that direct effect of organizational culture on job-satisfaction of 0.212 and indirect effect of organizational culture on job-satisfaction through organizational structure is $10.00 \%$. Total effect of organizational culture on job-satisfaction is $31,20 \%$,

Direct effect of organizational structure on job-satisfaction is $25,10 \%$. Total effect of organizational culture and organizational structure on job-satisfaction is $56,30 \%$,

The results showed that organizational culture and organizational structure contributes a moderately impact on job-satisfaction. This results give a relatively low contribution of $18,60 \%$ toward job-performance. It means that satisfaied teachers have a tendency to increase their job-perforance. Organizational structure changed from vertical structure to SBM and teachers certification program followed by certification salary contributed a moderate impact on job-satisfaction which was reported previously (Hutabarat, at al, 2014:261) which in turns increasing teacher job-performance. The findings also showed that organiztional culture contributed a relatively high impact on orga- nizational structure of $39.90 \%$. This result is acceptable due to the fact that organizational culture is considered as organizational glue which is assumed to drive a good organizational environtment to teachers and staffs at schools.

\section{CONCLUSIONS}

Based on data analysis and dicussions above, it is concluded that:

- Organizational culture directly and indirectly affected teacher job-performance of public high school in Medan

- Organizational structure changed from vertical structure to SBM which s followed by certification salary payment to certified teachers contributed a direct effect on teacher job-performance of the public high school teachers.

- Organizatioal culture, organizational structure and job-satisfaction at the same time contributed a positive direct and indirect effects on job-performance of the public high school teachers. .

\section{ACKNOWLEDGEMENT}

I would like to thank to Directorate of Higher Education for funding this research in 2014. I also would like to thank to Prof. Manihar Situmorang, Ph.D., and Prof. Parlin Pangaribuan, $\mathrm{Ph}$. D., for their contributions and supports in writing this articles.

\section{REFERENCES}

Adejumobi. F.T.and Ojikutu.R.K. 2013. School climate and teacher job performance in Lagos state Nigeria. Discourse Journal of Educational Research IJER. 1 (2); pp. 2636, June 2013

Ambarita, B. 2010. "Pengaruh Kepemimpinan Manajemen Personalia, Budaya Organisasi, Kepuasan Kerja dan Komitmen Organisasi terhadap Kinerja Dosen di Universitas Negeri Medan." Dissertation, Unpublished, Medan. Program Pasca Sarjana Universitas Negeri Medan. 
Ballou, D., and Podgursky, M. 1998. "The Case Against Teacher Certification. Public Interest". Summer, 1998. 132, pp. 16-29. http://faculty.missouri. edu / podgurskym/wp-content/uploads/1998/art19981.pdf.

Barge, J.D., 2012. "Making Education Work for all Georgians". Teacher Keys Effectiveness System Handbook. State School Superintendent. pp. 1-6

Caldwell. B.J. 2003. School Based Management, Synopsis, Third Education Forum in Education. Thailand.

Chiepe. G.B. 2004. Performance Resources, Joy in service: Integrated Performance Management System, Performance Measurement. Barbados.

Colquitt, J.A., LePine, J.A. and Wesson.M.J. 2009. Organizational Behavior, Improving performance and Commitment in the Workplace. Singapore: McGraw Hill. International Edition.,

Daft. R.I. 2005. The Leadership Experience., Owen Graduate school of Management, $3^{\text {rd }}$ Edition. Canada: Vanderhilt University.

Ehrenberg, R.G. 2003. "Studying Ourselves,: The Academic Labor Market". Journal of Labor Economics, 21. pp. 267-287.

Elsaid.N.M., Okasha.A.E., and Abdelghaly, A.A. 2013. "Defining and Solving the Organizational Structure Problems to Improve the Performanceof Ministry of State for Environmental Affairs-Egypt". International Journal of Scientific and Research Publications, 3,(10), October 2013. pp. 1-10.

Fahmi. M., Maulana. A., and Yusuf, A.S. 2011. "Teacher Certification in Indonesia: A Confusion of Means and Ends". Center for Economics and Development Studies (CEDS).Padjadjaran University. October, 2011. pp. 1-16.

Goldhaber, D. 2002. The Mistery of Good Teaching. Surveying the Evidence on Student Achievement and Teachers' Characteristics. 2(1). pp. 1-5. http://educationnext. org/the-mystery-of-good-teaching/.

Hutabarat, W., Situmorang, M., and Pangaribuan, P. 2014. "Effect Of Organizational Culture, Organizational Structure, And Work Motivation On Job Satisfaction of Senior High School Teachers In Medan, Indonesia". International Journal of Sciences: Basic and Applied Research (IJSBAR).. 16(1), pp 261-275.

Jalal, F. 2008. Rembuk Nasional. Depok: Departemen Pendidikan Nasional.

Upu. H. 2014. "Education Quality Improvement In Indonesia." Proceeding of International Conference on Research, Implementation and Education of Mathematics And Sciences 2014, Yogyakarta State University, 29-34.

Judge, A.T. 2001. "The Job-Satisfaction-Job Performance Relationship: A Qualitative and Quantitative Review". Psychological review, 127(3), pp. 376-407.

Lunenburg, F.C., and Ornstein, A.C. 2000, Educational Administration, Concepts and Practices. Third Edition. USA: Wadsworth

Miles, A and Sledge, S. 2006. "Satisfaction, Service and Culture: Relations from the Hotel Industry in Barzil, Mexico and Spain". Proceedings - AIB-SE (USA) Annual Meeting: Clearwater Beach.

Ololube, N.P. 2009. Teacher Job Satisfaction and Motivation for School Effectuveness: 
An assessment. Finland: University of Heksinki.

Penilaian Kinerja Guru 2008. Direktorat Tenaga Kependidikan Direktorat Jenderal Peningkatan Mutu Pendidik dan Tenaga Kependidikan Departemen Pendidikan Nasional, Kompetensi Evaluasi Pendidikan 04-03. Jakarta: Pengawas Sekolah Pendidikan Menengah.

Pisa. 2012. Results: Which Country Does Best at Reading, Maths and Science? Download Feb. $21^{\text {st }}, 2015: 10$ ":26 pm.

Robin, S.P. and Coulter, M. 2007. Management. New Jersey: Pearson International Edition.

Saari, L.M., and Judge, T.A. 2004. "Employee Attitudes And Job Satisfaction". Human Resource Management, 43 (4), pp. 395407.

Sabri. P.S.U., Ilyas. M., and Amjad. Z. 2011. "Organizational Culture and Its Impact on the Job Satisfaction of the University Teachers of Lahore". International Journal Of Business And Social Science 2(24). Special issue: December 2011, pp. 121-128.

Sanaky, A. H. 2011. Kompetensi dan Sertifikasi Guru: Sebuah Pemikiran. Sanaky. Com/ .../Kompetensi- Sertifikasi\%20gu.. download 21 November 2012 21:05 pm.

Schein H. E. 2004. Organizational Culrtue and Leadership., Third Edition, Jossey Bass: A Wiley imprint.

Slocum, J.W., and Hellriegel, D. 2009, Principles of Organizational Behavior. TwentiethEdition. South Western: Nelson Education, Ltd, Canada.

Siburian, P. 2012. "Pergaruh Budaya Organisasi, Perilaku Inovatis, Kepuasan Kerja, dan Motivasi Kerj terhadap Kinerja Kepala SMK". Dissertation, Pasca Sarjana Universitas Negeri Medan.

Suriansyah, A. 2014. "Hubungan Budaya Sekolah, Komunikasi, dan Komitmen Kerja Terhadap Kinerja Guru Sekolah Dasar Negeri". Cakrawala Pendidikan. Oktober 2014, Th. XXXIII,. 3, pp. 368-367.

Syamsudin, A. 2012. Permendiknas Peraturan Menteri Pendidikan dan Kebudayaan Republik Indonesia No. 5 tentang Sertifikasi Guru dalam Jabatan. Jakarta.

Tella.A., Ayeni.C.O.,and Popoola.S.O. 2007. "Work Motivation, Job Satisfaction, and Organizational Commitment of Library Personnel in Academic and Research Libraries in Oyo State, Nigeria". Library Philosophy and Practice. April. 2007. Pp. 1-16

The World Bank. 2007. What is School Based Management?. Washington DC: Education Human Development Network.

Tienken. C. 2008. "Rankings of International Achievement Test Performance and Economic Strength: Correlation or Conjecture". International Journal of Education Policy \& Leadership. April 25, 2008. 3 (4), pp.1-15.

Thierry, H. P. 1999. "Handbook of work and organizational psychology". Organizational Psychology, 4. pp. 253-326.

Viswesvaran. C., and Ones. D.S. 2000. "Perspectives on Models of Job-Performance". International Journal of Selection and Assessment, 8 (4), pp.216-226.

Weber. R.A., Camerer. C., and Selein. R. 2006, The Effects of Organizational Structure and Codes on the Performance of Laboratory 'Firms'. Pitsburg: Department of Social \& Decision Sciences, Carnegie Mellon University. 